\title{
Hubungan Antara Intimate Friendship Dengan Self Disclosure Pada Siswa Kelas XI SMA N 4 Kota Padang Pengguna Media Sosial Instagram
}

\author{
Sherly Febriani, Ifani Candra, Krisnova Nastasia \\ Fakultas Psikologi, Universitas Putra Indonesia “YPTK”Padang, Indonesia \\ Email: sherlyfebriani1998@gmai.com, ifani_candra@yahoo.com, krisnova88@gmail.com
}

\begin{abstract}
The aim of this research is to see whether there is a relationship between intimate friendship and selfdisclosure in class XI students of SMA N 4 Padang City, Instagram social media users. The dependent variable in this study is Self Disclosure and the independent variable is Intimate Friendship. Measuring instrument used in this study was largely skal a Intimate Friendship and Scale Self Disclosure. The sampling technique in this study is probability sampling, namely, a sampling technique that provides equal opportunities for each element (member) of the population to be selected as a sample member. The probability sampling technique used is simple random sampling. The sample in this study were 147 students of class XI SMA N 4 Padang City. The test results show the coefficient of validity on Intimate Friendship moves from 0,433 to 0.819 , while the coefficient of reliability is 0,962 , And the coefficient of validity on Self Disclosure move from 0,327 to 0,839 while the coefficient of reliability is 0,926 . Based on data analysis, correlation values of 0,165 with a level of signifi Kansi 0,046 which means that the hypothesis is accepted. This shows that there is a significant relationship between Intimate Friendship and Self Disclosure in class XI SMA N 4 Padang City Social Media Users Instagram . With the effective contribution of Intimate Friendship with Self Disclosure to class XI students of SMA N 4 Padang City, Social Media Users Instagram $3 \%$.
\end{abstract}

Keywords: Intimate Friendship, Self Disclosure, student.

\begin{abstract}
Abstrak
Tujuan dari penelitian ini adalah untuk melihat apakah ada Hubungan Antara Intimate Friendship dengan Selfdisclosure Pada Siswa Kelas XI SMA N 4 Kota Padang Pengguna Media Sosial Instagram”. Variabel dependen dalam penelitian ini adalah Keterbukaan Diri dan variabel independen adalah Intimate Friendship. Alat ukur yang digunakan dalam penelitian ini adaah skala Intimate Friendship dan Skala Self Disclosure. Teknik pengambilan sampel dalam penelitian ini adalah probability sampling yaitu, teknik pengambilan sampel yang memberikan peluang yang sama bagi setiap unsur (anggota) populasi untuk dipilih menjadi anggota sampel. Teknik probability sampling yang digunakan adalah simple random sampling. Sampel dalam penelitian ini adalah siswa kelas XI SMA N 4 Kota Padang yang berjumlah 147 orang. Hasil uji coba menunjukan koefisien validitas pada Intimate Friendship bergerak dari 0,433 sampai dengan 0,819, sedangkan koefisien reliability nya sebesar 0,962. dan koefisien validitas pada Self Discosure bergerak dari 0,327 sampai dengan 0,839 sedangkan koefisien reliabilitasnya sebesar0,926. Berdasarkan analisis data, diperoleh nilai korelasi sebesar 0,165 dengan taraf signifikansi 0,046 yang berarti hipotesis diterima. Hal ini menunjukkan bahwa ada hubungan yang signifikan antara Intimate Friendship dengan Self Disclosure Pada siswa kelas XI SMA N 4 Kota Padang Pengguna Media Sosial Instagram . Dengan besar sumbangan efektif Intimate Friendship dengan Self Disclosure pada siswa kelas XI SMA N 4 Kota Padang Pengguna Media Sosial Instagram 3\%.
\end{abstract}

Kata Kunci : Intimate Friendship, Self Disclosure, siswa.

\section{Pendahuluan}

Saat ini teknologi komunikasi telah berkembang pesat. Salah satu hasil perkembangan teknologi komunikasi ialah munculnya internet. Internet mengizinkan penggunanya untuk mengakses dan membagi segala bentuk informasi ke seluruh penjuru dunia. Seiring dengan berkembangnya internet, pengguna internet juga semakin banyak. Fenomena banyaknya pengguna internet ini juga terjadi di Indonesia. Berdasarkan situs Kompas.com sebanyak 3.4 juta pengguna lebih aktif bermedia sosial menggunakan perangkat mobile atau sebesar $45 \%$ dari total populasi manusia. Riset ini juga menampilkan data konsumsi media sosial dikalangan remaja usia 13-17 tahun. Total pengguna Facebook hingga akhir bulan juli 2019 mencapai 1,9 Miliar. Posisi kedua Snapchat denga total 66,9 juta pengguna usia 13-17. 369 juta untuk segala usia. Posisi ketiga, Instagram, yang memiliki 52,9 juta pengguna usia 13-17 tahun. Total pengguna instagram dari beragam usia mencapai 849,3 juta. Posisi

Diterima Redaksi: 1-11-2020 | Selesai Revisi: 10-2-2021 | Diterbitkan Online: 18-4-2021 
keempat ada Twitter dengan total pengguna usia 13-17 tahun sebanyak 20,2 juta. Total pengguna twitter beragam usia sebanyak 254 juta (https://www.google.com/amp/s/amp.kompas.com/tekno/read) Salah satu fasilitas yang yang dapat digunakan dengan internet adalah media sosial.

Media sosial merupakan salah satu konten di internet yang paling sering dan paling banyak diakses oleh pengguna internet. Berbagai fitur serta fasilitas ditawarkan untuk mendukung kemudahan penggunaan media sosial salah satunyauntuk berinteraksi dengan orang lain. Media sosial kini dimanfaatkan sebagai sarana untuk bersosialisasi, untuk bisa saling membagi ide, bekerja sama dan berkolaborasi untuk menciptakan kreasi,berpikir,berdebat,menemukan orang yang dapat menjadi teman, menemukan pasangan serta membangun sebuah komunitas, sehingga menggunakan media sosial menjadikan kita sebagai diri sendiri [1]. Saat ini, media sosial sangat berkembang dengan pesat.Berdasarkan situs dari Kompas.com, media sosial instagram menduduki posisi ketiga tertinggi yang banyak digunakan oleh remaja dengan rentang usia 13-17 tahun.

Salah satu media sosial yang digunakan oleh siswa-siswi adalah instagram. Berdasarkan situs Kompas.com, instagram menduduki posisi ketiga yang paling banyak digunakan oleh remaja usia 1317 tahun (usia siswa-siswi sekolah menengah atas).Banyak pengguna Instagram yang bertujuan untuk mengekspresikan kepribadiannya masing-masing melalui media sosial Instagram, salah satunya adalah untuk memenuhi kesenangan dan kepuasan dirinya melalui unggahan foto yang mereka lakukan. Mengunggah foto di Instagram dapat memberikan kebebasan berekspresi untuk memenuhi kepuasan tersendiri. Instagram adalah sebuah aplikasi berbagi foto yang memungkinkan pengguna mengambil foto, menerapkan filter digital, dan membagikannya ke berbagai layanan jejaring sosial, termasuk milik Instagram sendiri.Instagram berdiri pada tahun 2010 dan didirikan oleh dua bersahabat Kevin Systrom dan Mike Krieger. Tujuan umum dari Instagram itu sendiri salah satunya yakni sebagai sarana kegemaran dari masing-masing individu yang ingin mempublikasikan kegiatan, barang, tempat atau pun dirinya sendiri kedalam bentuk foto [2].

Keterbatasan ruang sosial serta ikatan emosional yang rendah terutama di kota-kota besar menimbulkan perubahan dalam pola interaksi masyarakat sehingga media sosial menjadi tempat untuk menyalurkan emosi. Di sisi lain ekspresi lewat media sosial juga tidak terlepas dari faktor eksternal yang dialaminya seperti tidak dapat mengekspresikan perasaannya pada lingkungan terdekat, termasuk orang tua, teman serta pasangan. Masalah-masalah yang dihadapi membuat orang membutuhkan ruang untuk mengekspresikan emosi namun karena keterbatasan ruang sosial menjadikan media sosial sebagai sarana untuk melakukan self disclosure [1].

Menurut Sears [3], pengungkapan diri atau keterbukaan diri (Self Disclosure) adalah kegiatan membagikan perasaan dan informasi yang akrab dengan orang lain. Morton [3] menyatakan bahwa pengungkapan diri dapat bersifat deskriptif atau evaluatif. Pengungkapan diri deskriptif, kita melukiskan fakta-fakta terkait diri kita yang mungkin belum diketahui oleh pendengar-pekerjaan, tempat tinggal kita, atau partai yang kita dukung di pemilihan umum, dan lain sebagainya. Pengungkapan diri evaluatif, kita mengemukakan pendapat atau perasaan pribadi jika kita menyukai orang-orang tertentu, bahwa kita merasa cemas karena terlalu gemuk, bahwa kita tidak suka bangun pagi.

Kehidupan sehari-hari, pengungkapan diri atau self disclosure berlangsung tidak hanya dalam komunikasi dan interaksi langsung antar manusia, tetapi dapat pula terjadi lewat media perantara, yaitu melalui media sosial, salah satunya adalah instagram. Salah satu bentuk pengungkapan diri (self disclosure) dalam media sosial instagram, yakni komunikasi yang disengaja lewat perilaku verbal yang menjelaskan mengenai pengalaman/perasaan seseorang. Pengungkapan diri melalui media sosial ini pada umumnya dilakukan dalam bentuk status, foto/video, chatting, komentar, dan lain-lain terkait kejadian yang dialami dan perasaan yang sedang dirasakan agar diketahui oleh sesama pengguna akun media sosial terkait [3].

Bentuk lain Self Disclosure (keterbukaan diri) dalam media sosial instagram adalah dengan adanya Instagram Story. Instagram Story membuat lebih dari 90\% pengguna isntagram membagikan informasi mengenai dirinya, seperti aktivitas yang sedang dilakukan hingga curhatan yang terkadang bersifat pribadi. Dengan adanya Instagram Story, seseorang dapat dengan bebas berbagi momenmomen aktivitas mereka. Dan banyak terjadi saat ini adalah curahan hati yang tak segan dibagikan melalui instagram [4].

Ada faktor yang mempengaruhi Self Disclosure (keterbukaan diri) yaitu besar kelompok, perasaan menyukai, efek diadik, kompetensi, kepribadian, topik bahasan, jenis kelamin. Salah satu dari faktor 
yang mempengaruhi Self Disclosure adalah Intimate Friendship (kedekatan berteman) yang terdapat dalam faktor perasaan menyukai. Individu akan lebih Self Disclosure kepada orang yang disukai daripada orang yang tidak disukai karena orang yang disukai akan memberikan dukungan positif terhadap Self Disclosure individu. Menurut De Vito [5] Jika terjadi hubungan timbal balik, artinya orang yang disukai juga menyukai individu sehingga keduanya saling menyukai dan merasa nyaman, maka Self Disclosure akan berlanjut, sebab individu banyak melakukan Self Disclosure kepada orang yang dipercaya atau bisa dikatan dengan orang terdekatnya. Dapat disimpulkan, individu akan melakukan Self Disclosure ketika dekat berteman. Setiap teman memiliki tempat tersendiri dalam hati individu, itulah hal yang membuat hubungan pertemanan istimewa [6]. Pertemanan akan menimbulkan intimasi (kedekatan) dalam berteman.

Menurut Toby [6] intimasi pertemanan (intimate friendship) ialah individu yang bisa membuat orang lain merasa nyaman untuk menceritakan tentang diri sendiri, berbagi keluh kesah, dan meminta solusi terhadap suatu permasalahan dengan pertanyaan yang lebih intim. Komunikasi akan semakin meningkat ketika mendapatkan keintiman. Intimasi pertemanan bermanfaat pada perkembangan kesehatan, fisik, mental untuk memiliki teman-teman pada umumnya dan rekan-rekan pada khususnya.

Menurut Punnyanunt-Carter [1] pengguna situs pertemanan sosial memaparkan informasi mengenai dirinya dengan intensitas yang cukup sering. Seorang melakukan self disclosure kepada orang yang ia rasa dekat dan dapat dipercaya guna menjaga informasi tersebut agar tidak tersebar luas ke khalayak umum, karenanya dibutuhkan suatu intimate friendship dalam melakukan self disclosure. Hal ini sesuai dengan pendapat Derlega yang mengemukakan bahwa seseorang akan lebih terbuka kepada orang dekat dengan, seperti suami/istri, keluarga, sahabat dekat dan biasanya pada orang yang disukai daripada orang yang tidak disukai.

Faktor yang mempengaruhi intimasi pertemanan berdasarkan penelitian yang dilakukan Beyers dan Seiffge-Krenke [7], yaitu awal perkembangan diri, pencapaian identitas rasional, dan fungsi integratif dari identitas rasional. Selain itu, pendapat berbeda diungkapkan Hatfield dan Rapson yang mengungkapkan faktor yang mempengaruhi intimasi pertemanan adalah kepercayaan, komunikasi nonverbal, cinta dan kasih sayang [7].

Berdasarkan hasil observasi dan wawancara yang dilakukan pada tanggal 7 November 2019 di SMA N 4 Kota Padang yang dilakukan kepada 15 orang siswa. 15 orang siswa tersebut menggunakan media sosial instagram. Media sosial yang pernah siswa-siswi gunakan adalah seperti facebook, instagram, dan lain-lain. Tetapi sudah tidak aktif lagi di media sosial facebook, siswa-siswi lebih aktif menggunakan media sosial instagram, dan ada juga yang tidak pernah menggunakan facebook. Juga, 15 orang siswa-siswi tersebut semuanya menggunakan instagram. Tujuan dari siswa-siswi menggunakan instagram adalah untuk bersosialisasi dengan teman-teman ketika tidak lagi berdekatan. Melalui instagram, siswa-siswi bisa mendapatkan teman baru yang bahkan dari luar daerah asalnya. Lewat instagram, siswa-siswi juga bisa chattingan mengenai apapun. Saling bercerita mengenai permasalahan yang sedang dihadapi ataupun kebahagiaan apa yang sedang dirasakan. Siswa-siswi merasa nyaman bercerita tentang kehidupannya kepada teman yang dekat dengannya. Siswa-siswi tersebut juga mengatakan, orang-orang yang baru dikenal melalui instagram sering mengomentari postingannya lalu bisa berlanjut dengan bercerita via Direct Message instagram. Rata-rata dari 15 orang tersebut tidak terlalu nyaman bercerita dengan orang yang baru mereka kenal. Siswa-siswi tidak terlalu membuka diri pada orang yang dikenal hanya dari sosial media. Karena siswa-siswi berpikiran, mereka tidak mengenal orang tersebut secara langsung, jadi ada ketakutan tersendiri jika rahasia ataupun cerita mereka menjadi tersebar. Siswa-siswi akan lebih bisa membuka diri dengan orang yang mereka kenal secara dekat melalui dunia nyata dan juga komunikasi melalui instagram. Ketika sedang berjauhan pun siswa-siswi tersebut tetap bisa bercerita atau melakukan Self Disclosure via instagram. Rata-rata following atau followers siswa-siswi tersebut di instagram adalah teman-teman yang dikenal langsung di dunia nyata. Baik itu sudah dekat berteman ataupun hanya sebatas pertemanan biasa. kedekatan dalam berteman terjalin karena kelas yang sama, dan untuk pergi jalan atau membuat tugas juga bersama. Siswa-siswi tersebut akan lebih mudah mengungkapkan tentang diri ataupun tentang permasalahan, kepada orang yang sudah dikenalnya dengan dekat. Mereka (siswa-siswi) merasa, rahasianya akan lebih terjaga dan aman.

Mereka (siswa-siswi) juga mengatakan dengan mengunggah foto, video di feed instagram ataupun instagram story, akan merasakan kepuasan tersendiri ketika mendapatkan like ataupun viewers yang 
banyak. Siswa-siswi mempunyai kesenangan tersendiri ketika mempunyai like ataupun viewers yang banyak, dan juga ketika ada orang yang mengomentari postingan mereka dengan perkataan yang positif. Siswa-siswi juga senang ketika teman dekatnya merespon ketika dia bercerita melalui instagram story.

Mereka (siswa-siswi) tersebut saling peduli dengan pertemanannya, seperti permasalahan dengan teman dekatnya, keluarga, dll. Karena sudah merasa dekat dan akrab dalam berteman. Jika dibandingkan dengan teman yang mereka kenal melalui sosial media, mereka akan lebih terbuka untuk bercerita dengan temannya yang secara langsung mereka kenal. Siswa-siswi tersebut saling membantu ketika ada diantaranya yang membutuhkan. Terkadang di saat susah pun, siswa-siswi akan tetap membantu teman sebisanya. Diluar sekolah pun, sering melakukan kegiatan bersama.

Siwa-siswi bercerita (curhat) terkadang menggunakan waktu yang lama, seperti membahas tentang asmara, keluarga, sekolah, dll. Siswa-siswi juga bercerita tentang hal-hal yang menyenangkan atau menyedihkan mengenai dirinya. Mereka (siswa-siswi) bercerita dengan sejujur-jujurnya mengenai permasalahannya ataupun kelebihan dan kekurangan tentang dirinya. Tetapi ketika bercerita dengan teman yang hanya dikenal di sosia media, mereka akan memilih cerita yang akan mereka bagikan. Siswa-siswa juga memilih cerita mana yang harus mereka bagikan dan cerita mana yang harus mereka simpan sendiri. Tetapi untuk orang terdekatnya, terkadang hal yang kecil sampai berat, akan diceritan dengan teman dekatnya.

\subsection{Self Disclosure}

Self disclosure menurut Derlega, et al. [6] adalah proses mengungkapkan informasi tentang dirinya kepada orang lain dan merupakan aspek penting dari komunikasi interpersonal untuk memiliki hubungan yang lebih dekat. Menurut Sears [3] pengungkapan diri atau keterbukaan diri (Self Disclosure) adalah kegiatan membagikan perasaan dan informasi yang akrab dengan orang lain. Pengungkapan diri menurut Jourard (dalam Gamayanti, dkk, 2018) berarti pembicaraan mengenai diri sendiri kepada orang lain sehingga orang lain mengetahui apa yang dipikirkan, dirasakan dan diinginkan oleh seseorang. De Vito [1] mengartikan Self Disclosure sebagai salah satu tipe komunikasi dimana informasi tentang diri yang biasadirahasiakan diberitahu kepada orang lain. De Vito [8] menyatakan bahwa keterbukaan diri (Self Disclosure) adalah suatu jenis komunikasi mengenai informasi tentang diri individu yang biasanya disembunyikan namun sebaliknya, hal itu dikomunikasikan kepada orang lain. Menurut Barak [8], Keterbukaan diri (Self Disclosure) mengacu pada perilaku komunikasi dimana seseorang mengungkapkan aspek dirinya sendiri mengenai informasi pribadi, pengalaman, pemikiran pribadi, dan perasaan pribadi.

\subsection{Aspek-Aspek Self Disclosure}

Aspek-aspek self disclosure diperoleh melalui dimensi self disclosure yang dikemukakan oleh De vito [1] berupa: (a)Amount / kuantitas : Kuantitas dari pengungkapan diri dapat diukur dengan mengetahui frekuensi dengan siapa individu mengungkapkan diri dan durasi dari pesan self-disclosing atau waktu yang diperlukan untuk mengutarakan statemen self disclosure individu tersebut terhadap orang lain. (b)Valensi : merupakan hal yang positif atau negatif dari penyingkapan diri. Individu dapat menyingkapkan diri mengenai hal-hal yang menyenangkan atau tidak menyenangkan mengenai dirinya, memuji hal-hal yang ada dalam dirinya atau menjelek-jelekkan diri individu sendiri. Faktor nilai juga mempengaruhi sifat dasar dan tingkat dari pengungkapan diri. (c)ketepatan dan kejujuran, dalam mengungkapkan diri. Ketepatan dari pengungkapan diri individu dibatasi oleh tingkat dimana individu mengetahui dirinya sendiri. Pengungkapan diri dapat berbeda dalam hal kejujuran. Individu dapatsaja jujur secara total atau dilebih-lebihkan, melewatkan bagian penting atau berbohong. (d) Intensi; Seluas apa individu mengungkapkan tentang apa yang ingin diungkapkan, seberapa besar kesadaran individu untuk mengontrol informasi-informasi yang akan dikatakan pada orang lain. (e) Intimacy; Individu dapat mengungkapkan detail yang paling intim dari hidupnya, hal-hal yang dirasa sebagai periperal atau impersonal atau hal yang hanya bohong.

\subsection{Intimate Friendship}

Menurut Toby [6] intimasi pertemanan (Intimate Friendship) ialah individu yang bisa membuat orang lain merasa nyaman untuk menceritakan tentang diri sendiri, berbagi keluh kesah, dan meminta solusi terhadap suatu permasalahan dengan pertanyaan yang lebih intim. Komunikasi akan semakin 
meningkat ketika mendapatkan keintiman. Intimasi pertemanan bermanfaat pada perkembangan kesehatan, fisik, mental untuk memiliki teman-teman pada umumnya dan rekan-rekan pada khususnya.

Menurut Santrock [9], intimate in friendship secara sempit diartikan sebagai pengungkapan diri atau membagi pemikiran-pemikiran pribadi. Pengetahuan yang mendalam dan pribadi tentang teman juga digunakan sebagai ukuran keakraban, sedangkan kesamaan diartikan dalam umur, jenis kelamin, etnis, dan faktor-faktor lainnya. Menurut Bickmore [9] intimate friendship adalah sebuah hubungan yang memungkinkan masing-masing individu untuk bergantung pada teman, memiliki kesamaan minat atau saling berbagi pengalaman, dan juga memiliki kualitas dalam self disclosure yang membuat individu dapat saling terbuka membicarakan pemikiran dan perasaannya masing-masing.

Sharabany [5] menyatakan bahwa intimasi pertemanan adalah hubungan pertemanan yang baik dalam kehidupan individu, dengan frekuensi hubungan lebih, dibandingkan teman lain yang menunjukkan kualitas persahabatan, dapat dilihat dari kejujuran,pengertian, kasih sayang, ekslusivitas, kepercayaan, dan kesetiaan.

Erikson, Rawlins [10] Secara interpersonal keintiman dalam berteman remaja mengilhami individu dengan rasa memiliki. Buhrmester, Parker \& Gottman [10]. Teman dekat juga berfungsi sebagai sumber penting dukungan emosional dan lingkungan yang aman untuk eksplorasi diri dan pembentukan identitas Kemampuan anak muda untuk membangun kepercayaan dan mengalami keintiman tergantung pada kapasitas mereka untuk mengungkapkan diri secara tepat (misalnya, untuk berbagi perasaan, pikiran, dan keinginan) dan untuk mengembangkan ikatan afektif dengan seorang teman, Parker\&Gottman, Sullivan, [10].

\subsection{Aspek-Aspek Intimate Friendship}

Aspek-aspek intimate friendship yang dikemukakan Sharabany [1] adalah: (a) Kejujuran dan spontanitas (frankness and spontaneity), merujuk pada hubungan yang meliputi keterbukaan dalam mengungkapkan kelebihan dan kelemahan diri sertamemberi pendapat secara terus terang mengenai apa yang dilakukan oleh orang lain. (b)Kepekaan dan pengertian (sensitivity and knowing), merujuk pada pengertian dan empati yang diimbangi dengan kesadaran untuk memahami. (c)Kelekatan (attachment), merujuk pada kedekatan dan kecocokan yang menghasilkanperasaan keterkaitan terhadap teman. (d)Eksklusifitas (exclusiveness), merujuk pada keunikan dalam suatu hubungan pertemanan yang menyebabkan tingkatannya lebih tinggi dibandingkan hubungan dengan orang lain. (e)Memberi dan berbagi (giving and sharing), merujuk pada teman yang akan memberikan barangbarang secara material dan juga dukungan sosial. (f)Penerimaan dan pengorbanan (taking and imposition), merujuk pada sikap mementingkan kepentingan teman di atas kepentingan pribadi serta menerima segala sifat yang dimiliki oleh teman, baik dan buruknya. (g)Kegiatan yang sama (common activities), menunjukkan bahwa memiliki ketertarikan dalam hal yang sama dan menikmati waktu yang dihabiskan dalam kegiatan bersama. (h)Kepercayaan dan kesetiaan (trust and loyalty), merujuk pada suatu kondisi dimana teman dapat menjaga rahasia dan akan saling membela satu sama lain dari ancaman luar.

Berdasarkan rumusan masalah di atas, maka tujuan dari penelitian ini adalah untuk melihat apakah ada Hubungan Antara Intimate Friendship dengan Self-disclosure Pada Siswa Kelas XI SMA N 4 Kota Padang Pengguna Media Sosial Instagram". 


\section{Metode Penelitian}

Jenis penelitian ini adalah kuantitatif korelasional dengan variabel penelitian menurut [11] variabel dependen nya adalah Self Disclosure (Y) dan variabel independent nya adalah Intimate Friendship (X). Populasi dalam penelitian ini adalah seluruh Siswa kelas sebelas SMA N 4 Kota Padang, yang berjumlah 314 orang. Teknik pengambilan sampel dalam penelitian ini adalah probability sampling yaitu, teknik pengambilan sampel yang memberikan peluang yang sama bagi setiap unsur (anggota) populasi untuk dipilih menjadi anggota sampel. Teknik probability sampling yang digunakan adalah simple random sampling.Jumlah populasi 314 orang dengan jumlah kekeliruan $10 \%$ berdasarkan tabel Isac dan Michael maka jumlah siswa yang dapat digunakan sebagai sampel penelitian adalah sebanyak 147.

Metode pengumpulan data yang digunakan dalam penelitian ini adalah skala. Model Skala yang digunakan pada Self Disclosure dan Intimate Friendship adalah modelskala likert.Skala Likert digunakan untuk mengukur sikap, pendapat dan persepsi seseorang atau sekelompok orang tentang fenomena sosial. Dengan skala Likert, maka variabel yang akan diukur dijabarkan menjadi indikator variabel. Kemudian indikator tersebut dijadikan titik tolak untuk menyusun item-item instrumen yang dapat berupa pernyataan atau pertanyaan [11]. Skala Likert terdiri dari pernyataan-pernyataan yang terdiri atas dua macam, yaitu pernyataan yang favorabel (mendukung atau memihak pada objek sikap) dan pernyataan yang unfavorabel (tidak mendukung objek sikap), [12].

Skala dalam penelitian ini memiliki format respon dengan empat alternatif jawaban, yaitu SS (sangat setuju), S (setuju), TS (sangat tidak setuju), dan STS (sangat tidak setuju).Skala penelitian ini akan melewati tahap analisis yaitu uji validitas, merupakan derajat ketepatan antara data yang terjadi pada objek penelitian dengan daya yang dapat dilaporkan oleh peneliti [11]. Suatu item dapat dianggap memiliki daya diskriminasi yang memuaskan jika berkorelasi signifikan terhadap skor total atau jika melakukan penilaian langsung terhadap koefisien korelasi bisa digunakan batas nilai berkriteria $r_{x y} \geq$ 0,3 [11]. Dan sebaliknya item skala dikatakan gugur jika koefisien korelasi lebih kecil dari $0,3\left(\mathrm{r}_{\mathrm{xy}} \leq\right.$ 0,3). Juga dilakukan uji normalitas menggunakan uji Kolmogrov-Smirnov. Uji Liniearitas bertujuan untuk mengetahui apakah dua variabel mempunyai hubungan yang linear atau tidak. Dua variabel dikatakan mempunyai hubungan yang linear bila signifikansi (liniearity) kurang dari 0,05.

\section{Hasil dan Pembahasan}

\subsection{Hasil}

Koefisien validitas skala Intimate Friendship memiliki nilai corrected item- total correlation berkisar antara 0,433 sampai dengan 0,819. Dengan koefisien reliabilitasnya sebesar 0,962. Koefisien validitas skala Self Disclosure memiliki nilai corrected item-total correlation berkisar antara 0,327 sampai dengan 0,839 dengan koefisien reliabilitas sebesar 0,926. Uji normalitas dalam penelitian ini menggunakan uji Kolmogrov-Smirnov, [13] menyatakan bahwa data dinyatakan berdistribusi normal jika signifikansi lebih besar dari 5\% atau 0,05.Berdasarkan hasil pengolahan data dengan menggunakan program IBM SPSS versi 21.0, maka diperoleh hasil sebagai berikut:

Tabel 1. Uji Normalitas Intimate Friendship dengan Self Disclosure

\begin{tabular}{ccccc}
\hline Variabel & $\mathbf{N}$ & $\mathbf{K S Z}$ & $\mathbf{P}$ & Sebaran \\
\hline Intimate Friendship & 147 & 0,960 & 0,315 & Normal \\
Self Disclosure & 147 & 1,314 & 0,063 & Normal \\
\hline
\end{tabular}

Berdasarkan tabel 1 di atas, maka diperoleh nilai signifikansi pada skala Intimate Friendship sebesar $\mathrm{p}$ $=0,960$ dengan $\mathrm{KSZ}=1,314$ hasil tersebut menunjukan bahwa nilai $\mathrm{p}>0,05$, artinya sebaran skala Intimate Friendship terdistribusi secara normal, sedangkan untuk Self Disclosure diperoleh nilai signifikansi sebesar $\mathrm{p}=0,063$ dengan $\mathrm{KSZ}=1,314$, hasil tersebut menunjukan bahwa nilai $\mathrm{p}>0,05$, artinya sebaran terdistribusi secara normal. 
Tabel 2. Uji Linieritas Skala Intimate Friendship dengan Self Disclosure

\begin{tabular}{ccccc}
\hline $\mathbf{N}$ & $\mathbf{D f}$ & Mean Square & $\mathbf{F}$ & Sig \\
\hline 147 & 1 & 411,163 & 5,527 & 0,021 \\
\hline
\end{tabular}

Berdasarkan tabel 2 di atas, diperoleh nilai $F=5,527$ dengan signifikansi sebesar $p=0,021(p<0,05)$, artinya varians pada skala Intimate Friendship dengan Self Disclosure tergolong linier.

Tabel 3. Hasil Uji Korelasi Antara Skala Intimate Friendship dengan Self Disclosure

\begin{tabular}{ccccc}
\hline $\mathrm{P}$ & $(\alpha)$ & Nilai Korelasi $(\mathrm{r})$ & $\mathrm{R}$ square & \multicolumn{1}{c}{ Kesimpulan } \\
\hline 0,046 & 0.05 & 0,165 & 0,027 & $\begin{array}{l}\text { sig (2-tailed) } 0,046<0,05 \text { level } \\
\text { of significant }(\alpha), \quad \text { berarti } \\
\text { hipotesis diterima. }\end{array}$ \\
\hline
\end{tabular}

Berdasarkan tabel di atas, maka diperoleh koefisien korelasi antara variabel Intimate Friendship dengan Self Disclosure yaitu sebesar $r=0,165$ dengan taraf signifikansi $p=0,046$. Hal ini menunjukkan adanya korelasi yang sangat rendah berarah positif atau searah antara kedua variabel tersebut, yang artinya jika Intimate Friendship tinggi, maka Self Disclosure juga tinggi, dan begitu juga sebaliknya.

Tabel 4. Descriptive Statistic Skala Intimate Friendship dengan Self Disclosure

\begin{tabular}{cc|ccccc}
\hline Variabel & $\mathbf{N}$ & \multicolumn{4}{|c}{ Empirik } \\
\cline { 3 - 6 } & & Mean & Std. Deviation & Minimum & Maximum \\
\hline Intimate Friendship & 147 & 93,29 & 9,016 & 61 & 122 \\
Self Disclosure & 147 & 88,67 & 10,172 & 51 & 119 \\
\hline
\end{tabular}

Berdasarkan nilai mean empirik tersebut, maka dapat dilakukan pengelompokkan yang mengacu pada kriteria pengkategorisasian dengan tujuan menempatkan individu kedalam kelompok-kelompok yang terpisah secara berjenjang menurut suatu kontinum berdasarkan atribut yang diukur [12]

Tabel 5. Kategori Intimate Friendship dengan Self Disclosure

\begin{tabular}{ccccc}
\hline Variabel & Skor & Jumlah & Persentase (\%) & Kategori \\
\hline \multirow{2}{*}{ Intimate } & $61-83$ & 17 & $12 \%$ & Rendah \\
Friendship & $84-101$ & 109 & $74 \%$ & Sedang \\
& $102-122$ & 21 & $14 \%$ & Tinggi \\
Self & $51-77$ & 15 & $10 \%$ & Rendah \\
Disclosure & $78-98$ & 118 & $80 \%$ & Sedang \\
& $99-119$ & 14 & $10 \%$ & Tinggi \\
\hline
\end{tabular}

Berdasarkan tabel 5 di atas dapat digambarkan bahwa 12\% siswa SMA N 4 Kota Padang mempunyai Intimate Friendship yang rendah, 74\% siswa SMA N 4 Kota Padang mempunyai Intimate Friendship yang sedang dan 14\% SMA N 4 Kota Padang mempunyai Intimate Friendship yang tinggi. Sementara itu ada 10\% siswa SMA N 4 Kota Padang Self Disclosure yang rendah, 80\% SMA N 4 Kota Padangmengalami Self Discosure sedang dan 10\% anggota SMA N 4 Kota Padang yang tinggi.

\subsection{Pembahasan}

Berdasarkan hasil uji korelasi Product Moment (Pearson) yang dilakukan dengan bantuan IBM SPSS versi 21.0, dimana level of significant $(\alpha) 0,05$ dan diperoleh nilai koefisien korelasi $\left(\mathrm{r}_{\mathrm{xy}}\right)=0,165$ dengan nilai (p) sig $=0,046$, menunjukan terdapat hubungan yang sangat rendah yang signifikan antara Intimate Friendship dengan Self Disclosure pada siswa SMA N 4 Kota Padang dengan arah positif, artinya hipotesis diterima.

Penelitian yang dilakukan oleh Sherly, dkk (2019) tentang Hubungan Intimasi Pertemanan dengan Self Disclosure Pada Mahasiswa Jurusan Kebidanan di Universitas Prima Indonesia menunjukkan bahwasanya ada hubungan yang positif antara Intimasi Pertemanan dengan Self Disclosure. Juga 
sejalan dengan penelitian oleh Anggraeni, dkk (2015) mengenai Hubungan Intimasi Pertemanan dengan Self Disclosure pada Mahasiswa Universitas Negeri Yogyakarta, bahwa adanya hubungan positif dan signifikan antara intimasi pertemanan dengan Self Disclosure.

Sharabany [5] menyatakan bahwa intimasi pertemanan adalah hubungan pertemanan yang baik dalam kehidupan individu, dengan frekuensi hubungan lebih, dibandingkan teman lain yang menunjukkan kualitas persahabatan, dapat dilihat dari kejujuran,pengertian, kasih sayang, ekslusivitas, kepercayaan, dan kesetiaan.

De Vito [8] menyatakan bahwa keterbukaan diri (Self Disclosure) adalah suatu jenis komunikasi mengenai informasi tentang diri individu yang biasanya disembunyikan namun sebaliknya, hal itu dikomunikasikan kepada orang lain. Pengungkapan diri memfasilitasi pengembangan dan pembentukan hubungan interpersonal yang murni dan bermakna.

Menurut Punnyanunt-Carter [1] pengguna situs perteman sosial media memaparkan informasi mengenai dirinya dengan intensitas yang cukup sering. Seorang melakukan Self-Disclosure kepada orang yang ia rasa dekat dan dapat dipercaya, guna menjaga informasi tersebut agar tidak tersebar luas ke khalayak umum, karenanya dibutuhkan suatu Intimate Friendship dalam melakukan SelfDisclosure.

Dilihat dari penilaian deskriptif terhadap 147 siswa dapat digambarkan bahwa 12\% siswa SMA N 4 Kota Padang mempunyai Intimate Friendship yang rendah, 74\% siswa SMA N 4 Kota Padang mempunyai Intimate Friendship yang sedang dan 14\% SMA N 4 Kota Padang mempunyai Intimate Friendship yang tinggi.

Sementara itu ada 10\% siswa SMA N 4 Kota Padang Self Disclosure yang rendah, 80\% SMA N 4 Kota Padangmengalami Self Discosure sedang dan 10\% anggota SMA N 4 Kota Padang yang tinggi.

Adapun sumbangan efektif dari variabel Intimate Friendshipterhadap Self Disclosure sebesar 3\%, dan 97\% lagi ditentukan oleh sumbangan variabel lain. Hasil tersebut menunjukan bahwa Intimate Friendship memberikan sumbangan yang rendah terhadap Self Disclosure, artinya masih ada beberapa faktor lain yang memberikan sumbangan terhadap Self Disclosure selain Intimate Friendship.

De Vito [5] faktor-faktor lain yang mempengaruhi self disclosure ada 7 yaitu besarnya ukuran kelompok, perasaan menyukai, efek diadik, kompetensi, kepribadian, topik bahasan, dan jenis kelamin. Faktor Intimate Friendship masuk kedalam faktor perasaan menyukai.

\section{Kesimpulan}

Berdasarkan hasil pengumpulan data dan analisis data yang telah dilakukan oleh peneliti, maka dapat ditarik kesimpulan yang sekaligus merupakan jawaban dari tujuan penelitian : Terdapat hubungan yang sangat rendah (sebesar 3\%, dima $97 \%$ lagi dipengaruhi oleh faktor lain) yang signifikan antara Intimate Friendship dengan Self Disclosure pada Siswa Kelas XI SMA N 4 Kota Padang dengan arah positif, yaitu semakin tinggi Intimate Friendship maka semakin tinggi pula Self Disclosure yang dimiliki oleh siswa. Begitu juga sebaliknya, semakin rendah Intimate Friendship maka akan semakin rendah pula Self Disclosure yang dimilikinya.

Adapun sumbangan efektif variabel intimate friendship terhadap self disclosureadalah sebesar 3\%. 


\section{DaftarRujukan}

[1] F. A. Pohan and H. A. Dalimunthe, "Hubungan Intimate Friendship dengan Self-Disclosure pada Mahasiswa Psikologi Pengguna Media Sosial Facebook," J. Divers., vol. 3, no. 2, p. 15, 2017.

[2] B. Mahendra, "Eksistensi Sosial Remaja Dalam Instagram (Sebuah Perspektif Komunikasi)," J. Visi Komun., vol. 16, no. 1, pp. 151-160, 2017.

[3] A. Sagiyanto and N. Ardiyanti, "Self Disclosure Melalui Media Sosial Instagram (Studi Kasus Pada Anggota Galeri Quote)," Nyimak (Journal Commun., vol. 2, no. 1, pp. 81-94, 2018.

[4] M. A. Oktavianti, "Instagram Stories Sebagai Media Self Disclosure Mahasiswi Ilmu Komunikasi Uinsa." p. 121, 2018.

[5] A. K. Puspita, "Hubungan Antara Self Disclosure Dengan Intimasi Pertemanan Pada Mahasiswa Universitas Negeri Yogyakarta Angkatan Tahun 2012.” Yogyakarta, 2015.

[6] A. K. Puspita, "Hubungan Antara Self Disclosure Dengan Intimasi Pertemanan Pada Mahasiswa Universitas Negeri Yogyakarta Angkatan Tahun 2012,” p. 2015, 2015.

[7] S. Sherly, S. Hartini, and Y. S. Manurung, "Intimasi Pertemanan ditinjau dari Self-Disclosure pada Mahasiswa Jurusan Kebidanan Universitas Prima Indonesia," J. Educ. Hum. Soc. Sci., vol. 2, no. 1, pp. 36-46, 2019.

[8] M. Shurur, "Hubungan Antara Keterbukaan Diri (Self Disclosure) dan Intensi Memanfaatkan Layanan Bimbingan Konseling terhadap Perilaku Agresif pada Remaja ( Siswa Kelas XI SMKN 4 Samarinda )," eJournal Psikol., vol. 4, no. 3, pp. 280-293, 2016.

[9] H. D. Kartika, "Hubungan Antara Sense Of Humor Dan Intimate Friendship Pada Remaja."

[10] N. Bauminger, R. Finzi-Dottan, S. Chason, and D. Har-Even, "Intimacy in adolescent friendship: The roles of attachment, coherence, and self-disclosure," J. Soc. Pers. Relat., vol. 25, no. 3, pp. 409-428, 2008.

[11] P. D. Sugiyono, Metode Penelitian Kuantitatif, Kualitatif, dan Tindakan. 2014.

[12] S. Azwar, Metode Penelitian Psikologi Edisi 2. Pustaka Belajar, 2017.

[13] D. Priyatno, Mandiri Belajar Analisis Data Dengan SPSS. 2013. 